\title{
Nias Ethnic Ornaments as an Idea Source for Handmade Batik Creation
}

\author{
Wahyu Tri Atmojo ${ }^{1}$, Misgiya ${ }^{2}$, Sriwiratma $^{3}$ \\ Fine Art Department FBS, Universitas Negeri Medan, Indonesia ${ }^{1,2,3}$ \\ wahyutriatmojo@unimed.ac.id
}

\begin{abstract}
The traditional Nias ethnic ornament has a unique and very varied form. It is opened widely to engineer, to develop and to visualize traditional Nias ethnic ornaments into a Batik technique. The artwork products are practical and non-functional artwork. Practical functional artwork is related closely to the needs of everyday human life, while non-functional artwork is only for displaying the values of beauty. The research was conducted by involving the students of Fine Art Department, FBS UNIMED. Research and development method included engineering ideas, exploring forms and developing designs that refer to the Nias ethnic ornaments. Specific method in this study was a research method of work creation by making alternative designs until finished designs. The process of making designs until finishing works referred to the theory of elements and fine art design principles which included composition and harmonization that were well arranged using Batik dye Napthol. From the design to the Batik process, the slanting, coloring, and sagging (removing the wax by boiling the cloth with water glass solution) until becoming a Batik work. The results of the batik process were carried out by designing a pattern to determine the types of practical functional products. The forms of work creation research were a cardigan (auteur), clothes, chair cushions, and long cloth that had non-functional artistic value. The handmade batik work of research result was analyzed in depth by involving experts from fashion and batik design experts. The result of the study was expected to be able to open up new jobs as creative industries. In addition, the creation research result that took ideas from the traditional Nias ethnic ornament could increase toward the repertoire of handmade batik art in Indonesia. The output of this study was scientific article that was sent to reputable journal internationally, while the additional output was Batik Textbook related to Batik Craft course.
\end{abstract}

Keywords: Creation, developing, ornaments, batik, Nias

\section{Introduction}

Nias is an archipelago that is integrated of the North Sumatra. Its local cultural resources are very varied. One of the local cultural resources is ornaments, ornaments is a part of the fine arts that can be processed sustainably giving benefits toward the society. It is opened widely to engineer, to develop, and to visualize traditional Nias ethnic ornaments through handmade Batik technique. Theoretically, the society and students obtain the knowledge relating toward the concept, and understanding of art and its scope. Practically, the main key in realizing the idea is expected to continue as a new job for students and the society. It is also related to the Batik Craft and Textile course as well as the Batik Craft Specialization course which is taught 
at Fine Art Department, FBS Unimed. The creation result is in the form of art work to show the beauty aspect. However, functional object are also created that are closely related to the daily human life needs. The first previous study about Batik research is contained in [1], the study explained that Malaysian traditional ornaments at North Sumatera are very feasible to be applied into the Batik technique.

The research was conducted to develop wings and to engineer or to explore ornaments found in Nias Island that could be implemented into batik technique. Nias Island as part of the North Sumatera, has a local culture resource such as a very diverse ornaments and it is worthy of being used as an idea source in conducting the research by creating and developing traditional Nias ornaments into written batik technique. Hopefully, it could increase creative industries in Nias Island, North Sumatra. However, based on observation, the im of Nias traditional ethnic ornaments as a local culture resource was still limited to certain fields.Not only that, but geographically its existence was also still in the local itself. Based the preliminary data above, the researcher was interested in conducting further research to visualize Nias ornaments on handmade Batik with the following formula. How do you visualize Nias ornaments into handmade Batik technique that was based on Nias ornaments? What creations could be created to visualize the Nias ornaments?

\section{Literature Review}

The ability to examine local content that contained a variety of traditional symbols provided an opportunity to build the creation foundation that did not merely change existing ones but also considered local uptake with a global feel. Thus, the findings of creative and innovative forms emerged. In visualizing the innovative forms of creation, creativity has a very important role. Creativity is the ability to produce new and useful work that has never been imagined before, both at the level of individuals and certain groups of people or a combination of abilities, knowledge, and motivation that is adapted to their environment [2].

The research maximized in applying traditional Nias ethnic ornaments into the field of batik art. Craft is a kind of art that produces a variety of quality furniture, decorative items, and elegant items [3]. Therefore, handicraft is a matter or diligent nature related to home industries that produces various types of goods that have artistic value to meet the daily needs of human life. Batik is a fabric stained by a dye technique with a batik wax barrier, with a characteristic pattern of ornaments design [4].

The research was explained that the traditional Batak ethnic ornaments could be identified, classified, and explored according to shape and type. After the three things were conducted, it was applied in making souvenir art that refer to the art tourism which reflected five special features.

From previous study, it was explained that even traditional ornaments could also be processed and developed into Batik technique. The ornaments developed into the batik technique produce Batak Batik motif with a dip bag. The coloring used napthol and salt with the Batak's characteristic colors which are red, black and white. Batak motif and special colors that are specific strength compared toward Batik that has appeared earlier. Thus, it was the reason of researcher to conceive Batak batik motifs.

The previous studies above illustrated the existence of traditional Batak ethnic ornaments strengthened that it could be utilized as an idea source in works of art creation. The artwork creation as souvenirs, in the batik technique that conducted the research, was to implement traditional Nias ethnic ornaments into batik craft work. The creation of batik craft that reflects the characteristic of Nias as a local flagship but it was packaged in such a way that had a global atmosphere and it was also expected to foster innovative creative industries in Nias. 


\section{Ornaments}

Ornaments is a branch of fine art in which many symbolic values or intentions are found which have something to do with the way of life or philosophy of life of human being or the society creator. In its form, ornaments can be in the form of two-dimensional or threedimensional in accordance with the style and style of each ethnicity. Each ethnic group in North Sumatra has cultural resources in the form of ornaments which are used as objects to be visualized in batik technique to produce handicraft products that have high economic value. Generally ornaments found in North Sumatra could be seen based on the shape of the picture, which was in the form of human form, animal shape, giant shape, plant form, geometric shape, and natural or cosmic form. The following are various kinds of ornamentss possessed by Nias ethnic groups, such as: niohulayo, niotalakhoi, niogama, niosolafiga, niotalinga woli-woli, niomeme, niobuaya, lasara, nioafi-afi, nioiozasai, niobutelai, bawi, I'a, fofo, bae, cia, and gogowaya [5]. Each type of ornaments has a certain symbolic meaning and is still believed by the local community. However, the forms of the ornaments will be used as a basic concept or framework in this study by creating batik craft art forms, so that batik art with a distinctive style and style of Nias as a local identity will be global. Craft is a matter of being diligent, gossip; industry, household handicraft company, non-machined handwork; handmade items. Based on the explanation above, it can be assumed, that handicraft is a matter or diligently related to the home industry that produces various types of furniture items, ornaments that have artistic value. Therefore in this research a creative industry will be created in the field of batik handicraft products with batik art products with Nias style. Ornaments art is a branch of fine art that has taken root in Indonesia as a satisfying sense of beauty and can be developed by adjusting human needs in the present and future [6]. Starting from prehistoric times in Indonesia until today, the existence of ornaments is always needed in everyday human life [7]. Each region also has an ornamental art. The type and style differ from one ethnic to others, one of type and style of ornamental arts that has certain characteristics is the traditional ethnic ornaments art of Nias North Sumatra. The issue of style in ornamentation will also involve the identity problem that is characteristic of the ornaments. A special mark is needed to distinguish one from another by mentioning its special characteristics because each object has certain characteristics. To know the depth of meaning requires sensitivity, foresight, and accuracy. The application of ornaments is also found in various objects, starting from metal objects, wood, leather, children's games and furniture [8].

Nias traditional ethnic ornaments art spread in North Sumatra region as a local cultural resource that is worthy of being used as a reference in the research process in order to create the batik craft industry so that batik art will appear with the ethnic style and style of Nias, North Sumatra. The creation process is by applying elements and principles of fine art design that are proportional between each other [9]. In this way, the continuity of new forms of work will be obtained which refers to the traditional forms of ethnic Nias art works, which further formulation of the model can be applied to the development of handicraft works in a broad way, especially in batik craft originating from ethnic arts. Therefore, it will add toward the repertoire of batik art in Indonesia through a type and style typical of Nias North Sumatra. The application of the Nias ornaments in batik technique is an effort to develop and provide opportunities as well as an alternative to find forms of batik that have certain characteristic [1]. Furthermore, the emergence of creative industries in the field of batik art would open job vacancy opportunities widely. Since, in the process of creating batik art works involving various human resources. Starting from the process of preparing the product, designing the image, to the technical implementation requires skilled and skilled human resources in accordance with their respective competencies. 


\section{Research Method}

The research conducted in two places. The first location was conducted in a craft studio room at Fine Art Gallery FBS Unimed. In the craft studio, students carried out the process of making designs and transferring it into Mori cloth. The second location was conducted at the Pendopo Art Studio. At the Sanggar Seni Pendopo, the students and the research team conducted a coloring process with Napthol and then sags (removes) the wax by boiling it using hot water and water glass. The population of the study was the number of Nias ethnic ornaments in the five regions of North Sumatera. The ornaments were: niohulayo, niotalakhoi, niogama, niosolafiga, niotalinga woli-woli, niomeme, niobuaya, lasara, nioafi-afi, nioiozasai, niobutelai, bawi, I'a, fofo, bae, cia, and gogaya. Taking of ornament form was conducted by purposive sampling technique [10]. This selection was made to choose the form of Nias ethnic ornaments which are considered to have certain values and are relatively easy to find in the field and visually appear to be aesthetic values. Data from various types and forms of ornaments were collected through library research. After the data were collected, the next process was to realize the selected data and then to visualize it in the form of batik art works using Mori cloth and the other equipment, such as canting, wax, and Naptol.

The research conducted with the research and development method, which is a method to emphasize product development therefore it can be applied in a broader context. There are some stages in conducting the research, starting from the initial survey, developing the design model, testing the design model, validating and socializing the model. The study was conducted by observing and documenting forms of traditional Nias ethnic ornaments, both in the library and in the research objects, namely in the ethnic Nias of North Sumatra. The ornaments form used as a reference for design and then visualized in the form of batik art. Nowadays, there are many types of batik art with patterns and styles that reflect regionalism, such as Cirebon batik, Pekalongan batik, Lasem batik, Yogyakarta batik, Solo batik, and others. This research will be conducted to create batik art with Nias ethnic type of style by exploring the traditional ornaments of Nias North Sumatra. 


\section{Results and Discussion}

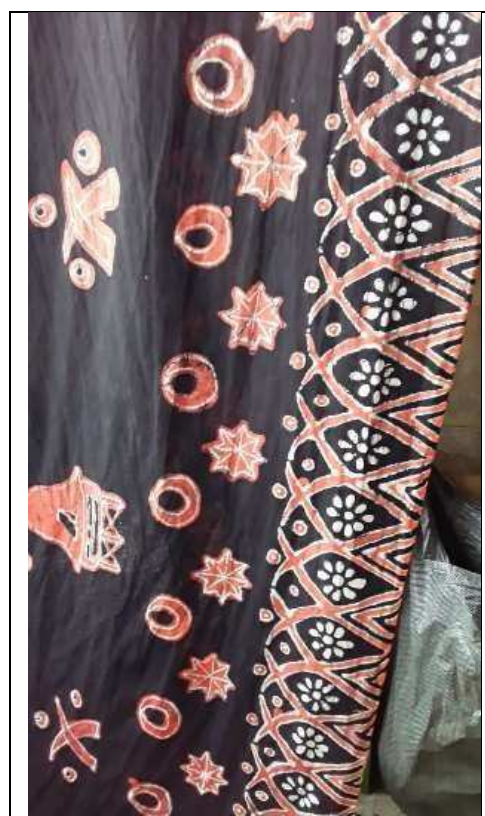

In figure 1, the types of traditional Nias motif of handmade Batik 1 applied were Niogama, Nioiozasai, Rumah adat Nias, Ni'ogolilimo, Niohulayo dan Nioafi-afi coming from Nias traditional. Motif Niogama, Ni'ogolilimo, Nioiozasai dan Nioafi-afi arranged in a longitudinal line on cloth. The form of patterns composition in the application of motifs on batik 1 was the process of repeating the shapes in a horizontal line. Niogama, Nioiozasai, Ni'ogolilimo and Nioafi-afi forms were arranged in the same position and the same distance. While the Nias traditional house was only one and it was right above of Niogama, Ni'ogolilimo, Nioiozasai dan Nioafi-afi motifs.

The technique of making batik with traditional Nias motifs guided the technique of making batik with handmade technique. The colors used were black, red, and white. The white one was used on Nioafi-afi and the white one also was used for contour line on motif Niogama, Ni'ogolilimo, Nioiozasai, Nias traditional house, and Nioafi-afi, in inside wasput orange colour, while theblack one was used as the base colour.

Fig 1. Handmade Batik 1

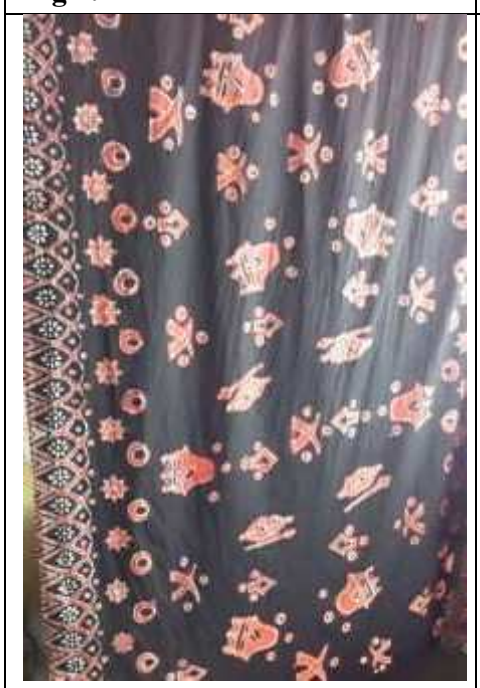

In figure 2, the types of Nias traditional motifs of handmade Batik 2 applied were Niogama, Nioiozasai, Nias traditional house, Ni'ogolilimo, Niohulayo, n Nioafi-afi, Niobutelai and Niotalakhoi (Niotawolo). In the Niobutelai and Niotalakhoi (Niotawolo) motifs were varied. However, they did not change from the original shapes, the traditional motifs are arranged in a long line in the fabric. The shape of the composition pattern in the application of ornaments was the process of repeating the form in a horizontal alignment.

The technique of making batik with traditional Nias motifs guided the technique of making batik with handmade technique. The colors used were black, red and white. White one was used for Nioafi-afi motif and it was also used for contour lines in Niogama, Nioiozasai,, Ni'ogolilimo, Nias traditional houses, and Nioafi-afi motif. Then, red one was used as a motif, and black was used as the base color.

Fig 2. Handmade Batik 2 


\begin{tabular}{|c|c|}
\hline 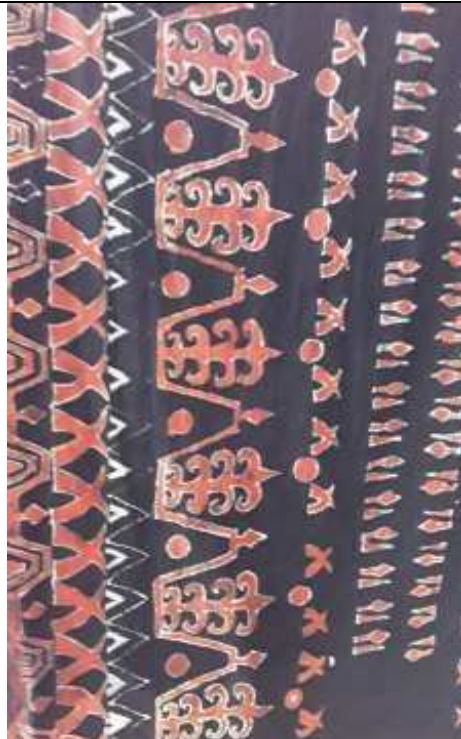 & $\begin{array}{l}\text { In figure } 3 \text {, the types of Nias traditional motifs of } \\
\text { handmade Batik } 3 \text { applied were Niohulayo, } \\
\text { Niotalakhoi (Niotawolo), Niotalinga Woli-Woli, } \\
\text { Nioiozasai, and Niobutelai motifs in a long array of } \\
\text { cloth lined up on the cloth itself. The shape of the } \\
\text { composition pattern in the application of motifs is } \\
\text { the process of repeating forms in a horizontal } \\
\text { parallel. Niohulayo motif, Niotalakhoi (Niotawolo), } \\
\text { Niotalinga Woli-Woli, Nioiozasai, and Niobutelai } \\
\text { motifs were arranged in the same position and the } \\
\text { same distance. } \\
\text { The technique of making batik with traditional Nias } \\
\text { motifs guided the technique of making batik using } \\
\text { handmade technique. The colors used were black, red } \\
\text { and white. The red color was used as the color of the } \\
\text { motif, the white color was used as the color of } \\
\text { Niohulayo motif and it was used as a contour line on } \\
\text { the Niotalakhoi (Niotawolo) motif, Niotalinga Woli- } \\
\text { Woli, Nioiozasai, and the Niobutelai motif, and } \\
\text { black as the base color. }\end{array}$ \\
\hline & \\
\hline $\begin{array}{l}\text { Fig 4. Handmade Batik 4(Practical } \\
\text { fungsional) T-shirt }\end{array}$ & $\begin{array}{l}\text { In this } 4 \text { handmade batik work, the types of Nias } \\
\text { traditional motifs applied were Nioafi-afi, } \\
\text { Niosolafiga, Nioiozasai motifs. The Niosolafiga } \\
\text { motif was modified. However, it did not reduce the } \\
\text { original shape. It was also modified to form a circle, } \\
\text { and Niosolafiga motif was modified in terms of } \\
\text { leaves and leaves, and Nioiozasai motif was also } \\
\text { modified however it did not reduce from the original } \\
\text { shape. The motifs that were combined and applied } \\
\text { are very varied with compositions that tend to be } \\
\text { symmetrical. } \\
\text { The technique of making batik with traditional Nias } \\
\text { motif guided the technique of making batik using } \\
\text { handmade technique. The colors used were white, } \\
\text { red, yellow and black according to the traditional } \\
\text { colors of Nias. In thefourth creation, white was used } \\
\text { in contrasting motifs, but red was used in the field of } \\
\text { Niozasai motifs, the middle circle of Nioafi-afi motif, } \\
\text { and red was also used as Niosolafiga color. Yellow } \\
\text { was used as the color of the Nioafi-afi motif and in } \\
\text { the Niosolafiga motif, and black was used as the } \\
\text { base color. }\end{array}$ \\
\hline
\end{tabular}




\begin{tabular}{|l|l|} 
In figure 5, the types of traditional Nias motifs of handmade \\
Batik applied were Nioiozasai, Nioafi-afi, Niosolafiga, \\
Niogama and Niobutelai motifs. Niosolafiga motif was \\
modified in the vine and there were leaves and Nioiozasai \\
motif was modified. Then, Niobutelai motif was also \\
modified but it did not reduce the original shape. In this \\
creation, it was made solid on the cloth. \\
The technique of making batik using traditional Nias motifs \\
guided the technique of making batik using handmade \\
technique. The colors used were white, red, yellow and black \\
related toward the traditional colors of Nias. The yellow color \\
was used on Nioafi-afi motif and Niogama motif, the red \\
color was used on the Nioi ozasai motif, Niosolafiga, and the \\
Niobutelai motif. Furthermore, the white color was used as a \\
contour on the motif, and the black color was used as the base \\
color.
\end{tabular}

\section{Conclusion}

The research was conducted in two stages. The first stage is the theoretical delivery to students who took Batik and textile craft subject and craft specialization subject. The theory given concerns the understanding of Batik, tools and materials as well as learning outcomes of batik and textile craft subject and craft specialization. The second stage is the process delivery of creating handmade Batik from the process of making designs to produce handmade batik and the process result in creating handmade batik that explored Nias ornaments. The creation produced in the form of handmade batik which has practical and non-practical functional. Cardigan Batik and T-shirt Batik are handmade, while non-practical functional was handmade work of art in the form of long cloth. The result of this handmade Batik could add to the Batik treasures in Indonesia.

\section{References}

[1] Atmojo, Wahyu Tri. Penciptaan Batik Melayu. PANGGUNG: Jurnal Ilmiah Seni \& Budaya. (2012).

[2] Sternberg, Robert J. and Todd I. Lubart. The Concept of Creativity: Prospects and Paradigm. New York: Cambridge University Press. (1999).

[3] Mulia, TGS, and Hidding. Ensiklopedia Indonesia, W. Van Hoeve. Bandung. (1972).

[4] Soesanto, Sewan. Seni dan Kerajinan Batik. Departemen Pendidikan dan Kebudayaan. Jakarta. (1984).

[5] Sirait, Baginda. Pengumpulan dan Dokumentasi Ornamen Tradisional di Sumatera Utara. Pemerintah Daerah Tingkat I Propinsi Sumatera Utara. (1980). 
[6] Gustami,SP. Nukilan Seni Ornamen Indonesia. Sekolah Tinggi Seni Rupa Indonesia. Yogyakarta. (1980).

[7] Sudarjo, Y. Ornamentik Indonesia. Sebelas Maret University Press. Surakarta. (1989).

[8] Meyer, Franz Sales. Hand Book of Ornament. Dover Publisher. Carlsruhe. (1892).

[9] Sipahelut, Atisah and Petrus Sumadi. Dasar-Dasar Desain. Departemen Pendidikan dan Kebudayaan. Jakarta. (1991).

[10] Hadi, Sutrisno. Metodology Research. Yayasan Penerbitan Fakultas Psikologi Universitas Gadjah Mada. Yogyakarta. (1982).

[11] Feldman, Edmun Burke. Art as Image and Idea. Printice-Hall Inc. New Jersey. (1967).

[12] Poerwodarminto, WJS. Kamus Umum Bahasa Indonesia. Balai Pustaka. Jakarta (1976).

[13] Sachari, Agus. Paradigma Desain Indonesia. Rajawali. Jakarta. (1986). 